\title{
Evidence supporting the use of recombinant activated factor VII in congenital bleeding disorders
}

This article was published in the following Dove Press journal:

Drug Design, Development and Therapy

26 June 2010

Number of times this article has been viewed
Background: Recombinant activated factor VII (rFVIIa, NovoSeven ${ }^{\circledR}$ ) was introduced in 1996 for the treatment of hemophilic patients with antibodies against coagulation factor VIII or IX. Objective: To review the evidence supporting the use of rFVIIa for the treatment of patients with congenital bleeding disorders.

Patients and methods: English-language databases were searched in September 2009 for reports of randomized controlled trials (RCTs) evaluating the ability of rFVIIa to restore hemostasis in patients with congenital bleeding disorders.

Results: Eight RCTs involving 256 hemophilic patients with antibodies against coagulation factors, also known as inhibitors, were identified. The evidence supporting the use of rFVIIa in these patients was weak with regard to dose, clinical setting, mode of administration, efficacy, and adverse events, given the limited sample size of each RCT and the heterogeneity of the studies.

Conclusion: The authors suggest that rFVIIa therapy in hemophilic patients with inhibitors should be based on the individual's ability to generate thrombin and form a clot, and not on the patient's weight alone. Therefore, assays for thrombin generation, such as whole-blood thromboelastography, have the potential to significantly improve the treatment of these patients.

Keywords: hemophilia, inhibitors, coagulation factor VIII, coagulation factor IX, rFVIIa, NovoSeven, FEIBA, hemostasis, RCT

\section{Introduction}

Hemophilic patients are subject to recurrent bleeding episodes that are associated with pain and disability; the most common type is musculoskeletal bleeding. Despite improvements in therapy, patients with severe hemophilia have a significantly reduced life expectancy, primarily due to liver disease, hepatocellular carcinoma, and intracranial hemorrhage. ${ }^{1}$

Some patients with hemophilia develop neutralizing, high-affinity polyclonal immunoglobulin $\mathrm{G}$ antibodies against the replaced coagulation factors. Such neutralizing antibodies are commonly known as inhibitors because they inactivate factors VIII (FVIII) and IX (FIX), with a higher incidence reported in hemophilia A than in hemophilia B. ${ }^{2}$ Specifically, the reported prevalence of inhibitor expression in patients with hemophilia A varies from $3.6 \%{ }^{3}$ to $32 \% .^{4}$ Many reasons for this wide range have been suggested, including variation in the proportion of moderately and severely affected patients, the therapeutic regimen (prophylactic vs therapeutic), the type of concentrate administered, the viral inactivation method used during production, and the method and frequency of inhibitor measurement. Coagulation-factor inhibitor development
Capital Region Blood Bank, Section Transfusion Medicine, Rigshospitalet, University of Copenhagen, Blegdamsvej 9 , DK-2100, Copenhagen, Denmark Tel +4523729202

Fax +4535390038

Email per.johansson@rh.regionh.dk 
also depends on the length of exposure to FVIII, the age at the time of first exposure, and the genetic background of the patient. ${ }^{2}$ There is a close correlation between mutation type and inhibitor development, so patients with less severe mutations have a lower likelihood of inhibitor expression than patients possessing severe mutations. ${ }^{5}$

The development of inhibitors is one of the most serious challenges in coagulation-factor replacement therapy and a major cause of morbidity and mortality in patients with hemophilia. ${ }^{6}$ The prophylactic use of FVIII in these patients is impractical, and the treatment of acute bleeding is difficult because the inhibitors hasten neutralization of infused FVIII, rendering it partially or completely ineffective. Additionally, elective surgery is rarely undertaken as the inhibitors make it difficult or even impossible to restore hemostasis during the perioperative period. Patients with low-titer, low-responding inhibitors (ie, peak titers $<5$ Bethesda Units $[\mathrm{BU}] / \mathrm{mL}$ ) face fewer clinical problems because hemostasis usually can be achieved by saturating the inhibitor with higher doses of the deficient factor. However, in patients presenting with high-titer, high-responding inhibitors $(>5 \mathrm{BU} / \mathrm{mL})$, the coagulation factor will be neutralized. As a result, other treatment modalities that diminish the levels of inhibitors (eg, plasmapheresis, immunoabsorption, and immune tolerance induction) and/or bypass their activity must be used.

FVIII inhibitor bypassing agent (FEIBA), specifically by an activated prothrombin complex concentrate (aPCC), has been used for decades as a hemostasis-bypassing agent in patients with high-responding inhibitors. ${ }^{7}$ Porcine FVIII is also efficacious in most patients with hemophilia A presenting moderate to high inhibitor titers, although its use has been limited by allergic transfusion reactions, thrombocytopenia, and brisk anamnesis. ${ }^{2}$ Recombinant activated factor VII (rFVIIa, NovoSeven $^{\circledR}$; Novo Nordisk A/S, Bagsværd, Denmark) was introduced in 1996 for the treatment of hemophilic patients with antibodies against FVIII or FIX. This agent was initially approved for the treatment of spontaneous or surgical bleeds in patients with inhibitors, with a recommended dosing schedule of $90 \mu \mathrm{g} / \mathrm{kg}$ rFVIIa every 2-3 hours until achievement of hemostasis. ${ }^{8}$ Then, in 2007, the European Medicines Agency (EMEA) approved the use of single-dose rFVIIa $(270 \mu \mathrm{g} / \mathrm{kg})$ to address mild to moderate bleeds in inhibitor-expressing patients with hemophilia. ${ }^{9} \mathrm{rFVIIa}$ is currently a first-line therapy for bleeding episodes in patients with congenital hemophilia A or B who express antibodies against coagulation factors and is also used to treat patients with acquired hemophilia. ${ }^{10-12}$ In Europe, rFVIIa has also been approved for the treatment of patients with congenital
FVII deficiency or Glanzmann's thrombasthenia, which may be refractory to platelet transfusion.

The administration of pharmacological doses of rFVIIa (ie, plasma concentrations of $25 \mathrm{nM}$, corresponding to $90 \mu \mathrm{g} / \mathrm{kg}$ dosing or higher) induces hemostasis in the absence of FVIII or FIX. The underlying mechanism is probably the enhancement of thrombin generation on the surface of thrombin-activated platelets, leading to a stable, near-normal fibrin clot network containing thin fibrin fibers and tightly packed fibrin strands that form a strong hemostatic plug. ${ }^{8}$ In a cell-based in vitro model of hemostasis, it was shown that rFVIIa binds to the thrombin-activated platelet surface with low affinity and that this binding requires higher concentrations of rFVIIa than those found normally in circulating blood. The bound rFVIIa activates factor X (FX) on the activated platelet surface, independent of the presence of FVIII or FIX. ${ }^{13}$ Also, rFVIIa inhibits fibrinolysis in vitro in hemophilia A plasma, thus prolonging the clot lysis time by inducing thrombin-activatable fibrinolysis inhibitor (TAFI). However, higher rFVIIa levels are still required to normalize fibrinolysis compared with the levels required to normalize clot formation. ${ }^{14}$ The hemostatic effect of exogenously administered rFVIIa at pharmacological doses is, thus, mediated by a combination of several factors, including enhanced thrombin generation rate, increased platelet activation and adhesion, and full activation of TAFI and FXIII.

This review presents evidence supporting the use of rFVIIa to treat congenital bleeding disorders with regard to dose, clinical setting (home vs hospital), mode of administration, indication (therapeutic vs prophylactic), efficacy, and adverse events.

\section{Methods}

English-language databases including MEDLINE, ScienceDirect, CINAHL, and Blackwell Science were searched in September 2009 for reports of randomized controlled trials (RCTs) testing the effect of rFVIIa on hemostasis in patients with congenital hemophilia A or B, congenital FVII deficiency, or Glanzmann's thrombasthenia. The keywords used, both individually and in combination, were recombinant activated factor VII, recombinant factor VIIa, recombinant FVIIa, rFVIIa, and NovoSeven ${ }^{\circledR}$. Hits using these keywords were cross-referenced with the terms used in clinical trial, randomized clinical trial, clinical study, randomized clinical study, and placebo-controlled study. References in the resultant articles were cross-checked for other potentially relevant studies. The inclusion criteria were as follows: (1) prospective, randomized trial; (2) use of rFVIIa; and 
(3) presence of a control group (placebo, other hemostatic agent, or a different dose of rFVIIa). The following studies were not included: (1) studies lacking a control group or randomization; (2) retrospective studies; (3) studies involving off-label use of rFVIIa; and (4) studies of rFVIIa combined with other hemostatic compounds. The end results of interest were achievement of hemostasis and development of thromboembolic adverse events.

\section{Results}

Eight RCTs involving 256 patients, who received study medication, were identified (Table 1). Two trials evaluated the effect of rFVIIa compared with FEIBA and 6 investigated the impact of different doses of rFVIIa (1 assessed prophylactic use and 1 evaluated the effect of bolus administration of rFVIIa compared with continuous infusion [CI]).

\section{Hemophilia coupled with coagulation-factor inhibitors}

The first study examined was performed by Shapiro et al. ${ }^{15}$ This prospective, double-blind study compared the outcomes of 35 and $90 \mu \mathrm{g} / \mathrm{kg}$ rFVIIa administered during and after elective surgery in patients with hemophilia. The patients received rFVIIa immediately before incision, intraoperatively

Table I Randomized clinical trials concerning rFVlla in hemophilia patients with inhibitors

\begin{tabular}{|c|c|c|c|c|c|}
\hline Study & Type & Intervention & $\begin{array}{l}\text { No } \\
\text { treated }\end{array}$ & $\begin{array}{l}\text { Response to } \\
\text { treatment }\end{array}$ & $\begin{array}{l}\text { Thrombotic } \\
\text { adverse event }\end{array}$ \\
\hline $\begin{array}{l}\text { Shapiro et al }{ }^{15} \\
\{1735\}\end{array}$ & Double-blind RCT & $\begin{array}{l}\mathrm{rFVIla} 35 \text { vs } 90 \mu \mathrm{g} / \mathrm{kg} \text { before } \\
\text { incision, then every } 2 \mathrm{~h} \text { or as } \\
\text { needed for } 48 \mathrm{~h} \text {, then every } \\
2-6 \mathrm{~h} \text { for } 3 \mathrm{~d} \text {, thereafter } \\
90 \mu \mathrm{g} / \mathrm{kg} \text { as needed }\end{array}$ & 29 & $\begin{array}{l}\text { Treatment successful: low } \\
\text { dose } 67 \% \text { vs high dose } 93 \% \text {, } \\
\text { being significant from day } 3 \\
\text { postoperatively, } P<0.05\end{array}$ & $\begin{array}{l}\text { I in the } \\
35 \mu \mathrm{g} / \mathrm{kg} \text { group }\end{array}$ \\
\hline $\begin{array}{l}\text { Lusher et al } \\
\{1730\}\end{array}$ & Double-blind RCT & $\begin{array}{l}\text { rFVIla } 35 \text { vs } 70 \mu \mathrm{g} / \mathrm{kg} \text { to } \\
\text { treat joint, muscle, and } \\
\text { mucocutaneous bleedings }\end{array}$ & 66 & $\begin{array}{l}\text { Treatment rated excellent in } \\
61 \%(35 \mu \mathrm{g} / \mathrm{kg} \cdot \text { group }) \text { vs } 57 \% \\
\text { (70 } \mu \mathrm{g} / \mathrm{kg} \cdot \text { group }), P=\mathrm{NS}\end{array}$ & None \\
\hline $\begin{array}{l}\text { Santagostino et } \text { al }^{16} \\
\{1734\}\end{array}$ & $\begin{array}{l}\text { Multicenter, open-label, } \\
\text { crossover RCT }\end{array}$ & $\begin{array}{l}\text { rFVIla } 270 \text { vs } 90 \mu g / k g \text { within } \\
6 \mathrm{~h} \text { of joint bleed every } 3 \mathrm{~h} \text {; } \\
\text { if not hemostasis at } 9 \mathrm{~h} \mathrm{Cl} \text {, } \\
90 \mu \mathrm{g} / \mathrm{kg} \text { up to } 24 \mathrm{~h} \text {, then } \\
\text { other options }\end{array}$ & 18 & $\begin{array}{l}\text { Hemostasis at } 9 \text { h } 25 \% \text { (high } \\
\text { dose) vs } 31 \% \text { low dose, } \\
P=N S \text {; number of Bls needed } \\
\text { in the high-dose }(n=I) \text { vs } \\
\text { standard-dose }(n=3) \text { groups, } \\
P=0.000 \text { I }\end{array}$ & None \\
\hline $\begin{array}{l}\text { Kavakli et al }{ }^{17} \\
\{1695\}\end{array}$ & $\begin{array}{l}\text { Multicenter, double-blind, } \\
\text { crossover RCT }\end{array}$ & $\begin{array}{l}\text { rFVIla } 270 \mu \mathrm{g} / \mathrm{kg}+0+0 \text { at } 3-\mathrm{h} \\
\text { intervals vs } 3 \times 90 \mu \mathrm{g} / \mathrm{kg} \text { at } 3-\mathrm{h} \\
\text { intervals at first and second } \\
\text { joint bleeding, or vice versa }\end{array}$ & 22 & $\begin{array}{l}65 \%(270 \mu \mathrm{g} / \mathrm{kg}) \text { vs } 70 \% \\
(3 \times 90 \mu \mathrm{g} / \mathrm{kg}) \text { achieved } \\
\text { hemostasis, } P=\mathrm{NS}\end{array}$ & None \\
\hline $\begin{array}{l}\text { Astermark et al }{ }^{18} \\
\{|7| 0\}\end{array}$ & $\begin{array}{l}\text { Multicenter, open-label, } \\
\text { crossover RCT }\end{array}$ & $\begin{array}{l}\text { I dose of FEIBA } \\
(75-100 \mathrm{IU} / \mathrm{kg}) \text { vs } 2 \text { doses } \\
\text { of rFVIla } 90-120 \mu \mathrm{g} / \mathrm{kg}\end{array}$ & 48 & $\begin{array}{l}\text { FEIBA }(80.9 \%) \text { and } \mathrm{rFVIla} \\
(78.7 \%) \text { exhibit similar effects } \\
\text { on joint bleeds, } P=0.059\end{array}$ & None \\
\hline $\begin{array}{l}\text { Konkle et a }\left.\right|^{19} \\
\{\mid 729\}\end{array}$ & $\begin{array}{l}\text { Double-blind, } \\
\text { crossover RCT }\end{array}$ & $\begin{array}{l}\text { rFVIla } 270 \text { vs } 90 \mu \mathrm{g} / \mathrm{kg} \text { daily } \\
\text { prophylaxis for } 3 \text { mo compared } \\
\text { with } 3 \text { mo preprophylactic and } \\
\text { postprophylactic periods }\end{array}$ & 22 & $\begin{array}{l}\text { Reduced bleeding frequency } \\
\text { by } 45 \%(90 \mu \mathrm{g} / \mathrm{kg}) \text { and } 59 \% \\
\text { ( } 270 \mu \mathrm{g} / \mathrm{kg}) \text {, both } P<0.00 \text { I; no } \\
\text { difference between dose groups }\end{array}$ & None \\
\hline $\begin{array}{l}\text { Pruthi et } \mathrm{al}^{20} \\
\{1736\}\end{array}$ & $\begin{array}{l}\text { Multicenter, } \\
\text { open-label RCT }\end{array}$ & $\begin{array}{l}\text { Preoperative bolus dose of } \\
90 \mu \mathrm{g} / \mathrm{kg} \text { and } \mathrm{BI} \text { every } 2 \mathrm{~h} \\
\text { during surgery till POD } 5 \text {. } \\
\text { Then every } 4 \mathrm{~h} \text { till POD } 10 \text { vs } \\
\mathrm{Cl} 50 \mu \mathrm{g} / \mathrm{kg} / \mathrm{h} \text { till POD } 5 \\
\text { and then } 25 \mu \mathrm{g} / \mathrm{kg} / \mathrm{h} \text { till POD } 10\end{array}$ & 24 & $\begin{array}{l}\text { Hemostatic efficacy was } 73 \% \\
\text { in } \mathrm{BI} \text { vs } 75 \% \text { in } \mathrm{Cl}, P=\mathrm{NS}\end{array}$ & $\begin{array}{l}\mathrm{I} \text { in the } \mathrm{BI} \\
\text { group }\end{array}$ \\
\hline $\begin{array}{l}\text { Young et } \mathrm{al}^{21} \\
\{|7| 9\}\end{array}$ & $\begin{array}{l}\text { Multicenter, double-blind, } \\
\text { crossover RCT }\end{array}$ & $\begin{array}{l}270 \mu g / \mathrm{kg}+0+0 \text { every } \\
3 \mathrm{~h} \text { vs } 3 \times 90 \mu \mathrm{g} / \mathrm{kg} \text { vs } 75 \mathrm{lU} / \mathrm{kg} \\
\text { FEIBA at time } 0\end{array}$ & 27 & $\begin{array}{l}\text { Rescue medication needed } \\
\text { within } 9 \mathrm{~h} \text { was } 8.3 \%(\mathrm{rFVIla} \\
270 \mu \mathrm{g} / \mathrm{kg}), 9.3 \%(3 \times 90 \mu \mathrm{g} / \mathrm{kg}) \\
\text { and } 36.4 \%(\mathrm{FEIBA}) \text {, respectively; } \\
\mathrm{rFVIla} 270 \text { and } 3 \times 90 \mu \mathrm{g} / \mathrm{kg} \text { vs } \\
\text { FEIBA, } P=0.032 \text { and } P=0.069 \text {, } \\
\text { respectively; no difference } \\
\text { between rFVIla dose groups }\end{array}$ & None \\
\hline
\end{tabular}

Abbreviations: $\mathrm{BI}$, bolus infusion; $\mathrm{Cl}$, continuous infusion; $\mathrm{POD}$, postoperative day; FEIBA, factor eight inhibitor bypassing agent; aPCC, activated prothrombin complex concentrate; NS, not significant. 
as needed, every 2 hours for the first 48 hours and every 2-6 hours for the following 3 days. After day 5, open-label rFVIIa $(90 \mu \mathrm{g} / \mathrm{kg})$ was available for the maintenance of hemostasis. Intraoperative hemostasis was achieved in 28 of 29 patients. All high-dose-treated patients and 12 of 15 low-dose-treated patients achieved satisfactory hemostasis over the first 48 hours after surgery. In 1 patient who had received the dose of $35 \mu \mathrm{g} / \mathrm{kg} \mathrm{rFVIIa}$, thrombosis of the right internal jugular vein developed on the second day following central venous catheter placement. The median total amount of rFVIIa administered was similar between the low-dose- and high-dose-treated groups, despite the reduction in the number of days of dosing required in surgical patients receiving the high dose. However, a statistically significant difference in efficacy from postoperative day 3 to 5 was reported, favoring the high-dose-treated group.

In a randomized, double-blind study, Lusher et al ${ }^{11}$ investigated the effect of 35 and $70 \mu \mathrm{g} / \mathrm{kg} \mathrm{rFVIIa}$ on hemostasis in hemophilia A and B patients with joint, muscular, and mucocutaneous bleeding and with or without the expression of coagulation-factor inhibitors. The results indicated that $35 \mu \mathrm{g} / \mathrm{kg}$ rFVIIa was statistically equivalent to the dose of $70 \mu \mathrm{g} / \mathrm{kg}$ rFVIIa with regard to hemostatic efficacy. Additionally, no thromboembolic adverse events were reported.

Santagostino et $\mathrm{al}^{16}$ reported a randomized multicenter, open-label, prospective crossover trial comparing the efficacy and safety of standard-dose $(90 \mu \mathrm{g} / \mathrm{kg}$ every 3 hours, as needed) and high-dose (single dose of $270 \mu \mathrm{g} / \mathrm{kg}$ ) rFVIIa for at-home treatment of 4 consecutive hemarthroses in 18 hemophilic patients with inhibitors. Patients not achieving hemostasis within 9 hours continued rFVIIa treatment in the form of repeated standard doses. Success rates for standard- and high-dose regimens were similar (31\% and $25 \%$ at 9 hours and $66 \%$ and $64 \%$ at 48 hours, respectively). The median number of rFVIIa infusions needed to achieve hemostasis was significantly greater for the standard-dose $(\mathrm{n}=3)$ than for the high-dose regimen $(\mathrm{n}=1, P=0.0001)$. Moreover, no thromboembolic events were reported.

A similar study, involving the at-home treatment of joint bleeds, was performed by Kavakli et al. ${ }^{17}$ In this multicenter, crossover, double-blind trial, patients were randomly selected to receive treatment for first joint bleed with a single dose of $270 \mu \mathrm{g} / \mathrm{kg}$ rFVIIa followed by 2 doses of placebo at 3-hour intervals and treatment for second joint bleed with 3 single doses of $90 \mu \mathrm{g} / \mathrm{kg}$ rFVIIa at 3-hour intervals, or vice versa. Efficacy was evaluated using a treatment-response rating scale based on the patient's assessment of pain and joint mobility. Treatment was rated as effective for $65 \%$ of patients' receiving a single dose of $270 \mu \mathrm{g} / \mathrm{kg}$ and for $70 \%$ of patients receiving the triple dose of $90 \mu \mathrm{g} / \mathrm{kg}(P=0.67)$, and no thromboembolic events were reported.

Astermark et $\mathrm{al}^{18}$ reported a randomized comparison of efficacy in patients treated with a single dose of FEIBA (75-100 IU/kg body weight; target dose, 85 IU/kg) and in patients treated with 2 doses of rFVIIa $(90-120 \mu \mathrm{g} / \mathrm{kg}$; target dose, $105 \mu \mathrm{g} / \mathrm{kg} \times 2$ ), with the second dose of rFVIIa administered 2 hours after the first. The hemostatic effect of the treatment was evaluated in patients after 2, 6, 12, 24, 36 , and 48 hours. No significant differences between the 2 treatment groups were identified at any time point, although FEIBA treatment was consistently associated with the highest efficacy ratings. Efficacy at 6 hours was $80.9 \%$ in FEIBAtreated and $78.7 \%$ in rFVIIa-treated patients $(P=0.059)$, and no thromboembolic events were reported.

A randomized clinical trial examining rFVIIa for secondary prophylaxis in hemophilic patients with coagulationfactor inhibitors was reported by Konkle et al. ${ }^{19}$ Thirty-eight patients entered a 3-month preprophylaxis period to confirm high baseline bleeding frequency (mean, $\geq 4$ bleeds per month). Twenty-two patients were randomized at a 1:1 ratio to receive daily rFVIIa prophylaxis at either 90 or $270 \mu \mathrm{g} / \mathrm{kg}$ for 3 months, followed by a 3-month postprophylaxis period. Bleeding frequency was reduced by $45 \%$ and $59 \%$ during prophylaxis with 90 and $270 \mu \mathrm{g} / \mathrm{kg}$ rFIIVa, respectively (both $P<0.0001$ ), and remained reduced during the postprophylaxis period. Patients reported significantly fewer hospital admissions and days absent from work or school during prophylaxis when compared with the preprophylaxis period. No significant differences were detected between the 2 doses, and no thromboembolic events were reported.

Pruthi et $\mathrm{al}^{20}$ investigated the efficacy of bolus infusion (BI) vs CI of rFVIIa in inhibitor-expressing hemophilia A and B patients undergoing major surgery. Safety was compared with that in a control group of patients lacking inhibitors and receiving FVIII or FIX concentrates before major surgery. All inhibitor-expressing patients received an initial bolus of $90 \mu \mathrm{g} / \mathrm{kg} \mathrm{rFVIIa}$ and were then randomly assigned to the BI $(\mathrm{n}=12)$ or $\mathrm{CI}(\mathrm{n}=12)$ group. The BI group received $90 \mu \mathrm{g} / \mathrm{kg}$ rFVIIa every 2 hours during surgery till day 5 , followed by $90 \mu \mathrm{g} / \mathrm{kg}$ rFVIIa every 4 hours from day 6 to 10 . Meanwhile, the CI group received $50 \mu \mathrm{g} / \mathrm{kg}$ rFVIIa every hour till day 5 , followed by $25 \mu \mathrm{g} / \mathrm{kg}$ rFVIIa every hour from day 6 to 10 . The hemostatic efficacy of rFVIIa in each treatment group was comparable, with efficacy demonstrated in 8 of $11(73 \%)$ and 9 of $12(75 \%)$ subjects in the BI and CI groups, respectively, and inefficacy observed in 3 subjects per group. 
Young et $\mathrm{al}^{21}$ evaluated the efficacy and safety of rFVIIa and FEIBA treatments for controlling joint bleeds in an at-home treatment setting. Patients received each of 3 treatments in 1 of 6 possible sequences: (1) $270 \mu \mathrm{g} / \mathrm{kg}$ rFVIIa at hour 0 plus placebo at hours 3 and 6; (2) $90 \mu \mathrm{g} / \mathrm{kg} \mathrm{rFVIIa}$ at hours 0, 3, and 6; and (3) $75 \mathrm{IU} / \mathrm{kg}$ FEIBA at hour 0. Efficacy was assessed based on the need for rescue treatment within 9 hours of administration of the trial drugs. The percentage of patients treated with $270 \mu \mathrm{g} / \mathrm{kg} \mathrm{rFVIIa}$, who required additional hemostatic treatment within 9 hours $(8.3 \%)$, was significantly lower than that of the FEIBA-treated group (36.4\%, $P=0.032$ ), whereas the percentage of patients treated with $90 \mu \mathrm{g} / \mathrm{kg}$ rFVIIa, who required such rescue medication $(9.1 \%, P=0.07)$, was not significantly lower than that of the FEIBA-treated group. Throughout the study, no safety issues were identified.

\section{Thrombophilia and acquired FVIla deficiency}

No randomized controlled studies conducted in patients with Glanzmann's thrombasthenia, Bernard Souliers syndrome, or acquired FVIIa deficiency were identified.

\section{Discussion}

This review identified 8 randomized clinical studies evaluating the hemostatic efficacy of rFVIIa treatment in inhibitorexpressing patients with hemophilia A or B. The total number of patients treated was 256 , with the majority of studies enrolling fewer than 30 patients. This small sample size significantly limited the ability to form conclusions about the efficacy and safety of rFVIIa treatment in these patients. Specifically, 6 studies evaluated different doses of rFVIIa in surgical and at-home treatment settings, ${ }^{11,15-17,20,21}$ and 2 studies compared the efficacy of rFVIIa with that of FEIBA. ${ }^{18,21}$

\section{Dose evaluation}

With regard to the optimal dose of rFVIIa, initial studies evaluated low doses in patients undergoing surgery (35 vs $90 \mu \mathrm{g} / \mathrm{kg})^{15}$ and in patients with joint, muscular, and mucocutaneous bleeding ( $35 \mathrm{vs} 70 \mu \mathrm{g} / \mathrm{kg}$ ). ${ }^{11}$ More recent research has compared repeated doses of $90 \mu \mathrm{g} / \mathrm{kg} \mathrm{rFVIIa}$ with single doses of $270 \mu \mathrm{g} / \mathrm{kg}$ rFVIIa in an at-home treatment setting. ${ }^{16,17,21}$ Shapiro et al ${ }^{15}$ reported that high-dose rFVIIa $(90 \mu \mathrm{g} / \mathrm{kg})$ administered to patients undergoing surgery exhibited $93 \%$ hemostatic efficacy compared with $67 \%$ efficacy presented by the low-dose $(35 \mu \mathrm{g} / \mathrm{kg}$ ) group, and the efficacy in these 2 groups varied significantly beginning postoperative day 3 . Additionally, 5 patients were found to have hemostatic treatment failures, requiring an "escape" dose of up to $180 \mu \mathrm{g} / \mathrm{kg} \mathrm{rFVIIa}$ or alternative hemostatic therapy and also leaving the study group. All of these patients except one were in the low-dose group, and it was concluded that the dose of $90 \mu \mathrm{g} / \mathrm{kg}$ rFVIIa was appropriate for surgical interventions. This finding was recently challenged by Obergfell et $\mathrm{al},{ }^{22}$ who reviewed published data on elective orthopedic surgical procedures in inhibitor-expressing patients with hemophilia from January 2002 to November 2006. They found that most bleeding complications could be resolved by increasing the rFVIIa dose or administering an extra dose and concluded that the optimal initial rFVIIa bolus dose for orthopedic surgery may be higher than $90 \mu \mathrm{g} / \mathrm{kg}$. Furthermore, in the major orthopedic interventions reported by Solimeno et $\mathrm{al}^{23}$ and Rodriguez-Merchan et al, ${ }^{24}$ bleeding complications were only observed in patients receiving the dose of $90 \mu \mathrm{g} /$ $\mathrm{kg}$ rFVIIa. Based on these data, a minimum initial dose of $120 \mu \mathrm{g} / \mathrm{kg} \mathrm{rFVIIa}$, followed by a similar or $90 \mu \mathrm{g} / \mathrm{kg}$ dose every 2 hours, was suggested for patients in the BI group. ${ }^{22}$

\section{At-home treatment}

With regard to the at-home treatment of joint bleeds in hemophilic patients with coagulation-factor inhibitors, 4 RCTs have been reported. Lusher et $\mathrm{al}^{11}$ evaluated low-dose rFVIIa (35 vs $70 \mu \mathrm{g} / \mathrm{kg}$ ), with approximately $60 \%$ of patients in each group reporting excellent efficacy for the treatment of joint bleeds. Later investigations of joint bleeds compared a single high dose of rFVIIa $(270 \mu \mathrm{g} / \mathrm{kg})$ with a standard dose of rFVIIa $(90 \mu \mathrm{g} / \mathrm{kg})$ every 3 hours..$^{16,17,21}$ With regard to hemostatic efficacy, no significant differences were observed between treatment groups in any of the studies. The percentage of patients reporting a successful response to rFVIIa treatment varied from $31 \%$ to $66 \%$, which is well below the $80 \%-90 \%$ efficacy rating reported in the literature for nonrandomized trials. ${ }^{10,25}$ The percentages are also lower than that reported by Goldstein et al, ${ }^{26}$ who determined that rFVIIa treatment administered by the Hemophilia and Thrombosis Research Society from 2000 to 2008 was effective in $74 \%$ of adult patients. The reason for this discrepancy is unclear because RCTs and observational studies are generally expected to yield similar efficacies. ${ }^{27,28}$ However, the high hemostatic efficacy of rFVIIa reported in the nonrandomized observational studies may be because such studies are more likely to include a broad range of patients with coexisting illnesses, a wide spectrum of disease severity, and treatment tailored to the individual. Because the risk profile of the patient affects the choice of drug, confounding variables may be introduced by different treatment regimens. In contrast, 
RCTs typically enroll patients who are highly selected, considered fit to enter the trial, likely to finish the trial, and believed or demonstrated to comply with medication. This patient population is quite different from that encountered during routine clinical practice. Furthermore, the low number of subjects included in the RCTs reported here ${ }^{11,16,17,21}$ may also explain the broader and thus less precise efficacy ranges compared with larger observational studies that include more subjects. ${ }^{10,25}$

Administration of a single high dose of rFVIIa offers many advantages, such as less pain and reduced number of needle sticks and infusions. Additionally, single high-dose administration may facilitate patient compliance and improve the feasibility of at-home treatment or self-administration. At-home treatment itself can facilitate early intervention, resulting in increased treatment efficacy due to decreased intervention time. ${ }^{25}$ No significant difference in hemostatic efficacy, as evaluated by grading the patients' perception of pain and mobility following rFVIIa treatment ${ }^{16,17,21}$ and/or by the need for rescue medication, ${ }^{17,21}$ was found between repeated standard-dose and single high-dose rFVIIa administration in the RCTs reported here. As a result, high-dose rFVIIa $(270 \mu \mathrm{g} / \mathrm{kg})$ was approved by the EMEA in 2007. It should be noted, however, that 3 RCTs performed till date only involved 67 patients in total, making it difficult to exclude the possibility that a significant difference actually exists between the treatment regimes.

\section{Bolus vs $\mathrm{Cl}$}

One study compared repeated BIs of rFVIIa with CI in 24 inhibitor-expressing hemophilic patients undergoing major orthopedic surgery. ${ }^{20}$ It was found that the hemostatic efficacy at the end of the study was comparable for perioperative BI and CI (73\% and 75\%, respectively). As predicted, the dosing schedule of rFVIIa resulted in different daily and cumulative doses in the CI and BI groups; during and up to 72 hours after the operation, the dose was greater in the CI group than in the BI group (292.2 vs $237.5 \mathrm{mg}$, respectively). The treatment efficacy reported by Pruthi et $\mathrm{al}^{20}$ is somewhat lower than that reported by Ludlam et al, ${ }^{29}$ who reported a hemostatic efficacy of $89 \%$ in 9 inhibitor-expressing patients undergoing major surgery and treated the patients with the same dosing scheme as that of the CI group. It should be noted, however, that 4 of 9 patients received tranexamic acid. Similarly, Santagostino et $\mathrm{al}^{30}$ described 11 inhibitorexpressing patients undergoing major surgery who received a CI dose of only $20 \mu \mathrm{g} / \mathrm{kg}$ rFVIIa per hour together with tranexamic acid, demonstrating hemostatic efficacy in 9 of the 11 patients $(81 \%)$. In contrast, Smith et $\mathrm{al}^{31}$ used a fixed dose of $16.5 \mu \mathrm{g} / \mathrm{kg}$ rFVIIa per hour without tranexamic acid and reported a hemostatic efficacy of only $33 \%$. From these data, we can conclude that CI at a dose of $50 \mu \mathrm{g} / \mathrm{kg}$ rFVIIa per hour after a standard bolus dose of rFVIIa results in an acceptable hemostatic efficacy. Additionally, it may be beneficial to consider adjunctive treatment with tranexamic acid. An RCT comparing the hemostatic efficacy of CI alone and $\mathrm{CI}$ in conjunction with tranexamic acid is, thus, warranted.

\section{rFVIla vs FEIBA (aPCC) treatment}

Two of the reviewed studies compared rFVIIa with FEIBA as an at-home treatment in inhibitor-expressing patients with joint bleeds. ${ }^{18,21}$ When comparing the hemostatic efficacy of a standard dose of rFVIIa $(90 \mu \mathrm{g} / \mathrm{kg})$ infused $2^{18}$ or 3 times ${ }^{21}$ with that of a single dose of FEIBA (75-100 IU/kg), highly different results emerge. In the study by Astermark et al ${ }^{18}$, 2 treatments resulted in a similar hemostatic efficacy ( $81 \%$ for FEIBA vs $79 \%$ for rFVIIa), whereas Young et $\mathrm{al}^{21}$ reported a successful response, as evaluated by the need for rescue medication, in only $54 \%$ of the FEIBA-treated patients compared with $91 \%-92 \%$ in the rFVIIa-treated patients. The difference in the response to rFVIIa between the 2 studies may be partly explained by different dosing schedules. The patients examined by Young et $\mathrm{al}^{21}$ received 3 doses at 3-hour intervals, while those of the Astermark et al ${ }^{18}$ study received only 2 doses. With an estimated rFVIIa half-life of approximately 120 minutes, 3 doses would result in higher peak thrombin generation, maintaining elevated thrombin levels for a longer time than 2 doses.

However, the reason for the different hemostatic response to FEIBA reported by 2 research groups is less obvious. The hemostatic efficacy of FEIBA has previously been observed to vary from $80 \%$ to nearly $100 \%$ under different conditions, including at-home treatment of spontaneous or traumatic bleeds and major and minor surgery. ${ }^{32-34}$ Possible explanations for the discrepancy in treatment efficacy observed between RCTs and observational studies may involve different study populations, as mentioned earlier. Differences in dose and dosing frequency, ancillary hemostatic therapy, efficacy criteria, and time points at which efficacy was evaluated may also contribute significantly to the observed discrepancies. ${ }^{21,32-34}$ Furthermore, it could be argued that because the standard recommended dose of FEIBA is 50-100 IU/kg every 4-6 hours, and the standard dose of rFVIIa is $90 \mu \mathrm{g} / \mathrm{kg}$ every 2-3 hours until hemostasis is achieved, the doses administered to the FEIBA and rFVIIa treatment groups were markedly unmatched. This is because 
the treatment efficacy depends on the administered dose of FEIBA. ${ }^{34}$ This was illustrated in 6 hemophilic patients with coagulation-factor inhibitors who experienced 61 bleeds that were treated with FEIBA. Definite cessation of bleeding was demonstrated in $93 \%$ of the patients receiving a cumulative median dose of $205 \mathrm{IU} / \mathrm{kg}$ per event. ${ }^{34}$ The authors observed that FEIBA treatment stopped the hemorrhaging later than rFVIIa treatment but resulted in a lower number of rebleeding episodes. ${ }^{34}$

\section{rFVIla for secondary prophylaxis}

One group compared the effect of 90 and $270 \mu \mathrm{g} / \mathrm{kg}$ rFVIIa on bleeding frequency for secondary prophylaxis in inhibitorexpressing patients with frequent bleeding episodes. ${ }^{19}$ Bleeding frequency was essentially halved during the 3-month prophylaxis using 2 doses of rFVIIa when compared with that during the 3-month preprophylaxis period (median value for target joint bleeds per 3 months, 11.5 vs 4 for $90 \mu \mathrm{g} / \mathrm{kg}$ dose and 9 vs 2.5 for $270 \mu \mathrm{g} / \mathrm{kg}$ dose, both $P<0.001$ ). Intriguingly, the reduction in bleeding frequency persisted during the 3-month postprophylaxis period (median value for target joint bleeds per 3 months, 5 for $90 \mu \mathrm{g} / \mathrm{kg}$ dose and 5 for $270 \mu \mathrm{g} / \mathrm{kg}$ dose, both $P<0.01$ ), and it was suggested that this reduction may be due to a reduction in the inflammation associated with chronic synovitis. Although secondary prophylaxis appears to be a promising alternative to on-demand therapy in hemophilic patients lacking inhibitors, ${ }^{35,36}$ evidence supporting secondary prophylaxis over on-demand treatment was previously derived from small observational studies and clinical case reports. Although several case reports describe an excellent response to secondary rFVIIa-based prophylaxis in patients with high titers of inhibitors suffering from frequent bleeding, ${ }^{37-39}$ there is little scientific evidence supporting the efficacy of such therapy, besides the RCT presented here. ${ }^{19}$

\section{Treatment efficacy evaluation}

As outlined above, considerable difficulty exists in evaluating rFVIIa treatment in inhibitor-expressing patients with hemophilia. This is due to the apparent lack of standardization in the evaluation of hemostatic efficacy. For the at-home treatment setting, ${ }^{11,16-18,21}$ treatment success was evaluated by the patients themselves in 4 studies, ${ }^{16-18,21}$ whereas the efficacy was judged by the investigators in 1 study. ${ }^{11}$ Another investigation used the patients' perception of whether the treatment was effective, partially effective, poorly effective, or not effective and if the bleeding had stopped. ${ }^{18}$ Meanwhile, the remaining 3 studies graded the patients' perception of pain and mobility following rFVIIa treatment. ${ }^{16,17,21}$ Two of the studies additionally used the need for rescue medication as a marker of effectiveness. ${ }^{17,21}$ Also, different time points for the evaluation of hemostatic efficacy were used, with 1 group using 6 hours, ${ }^{18} 1$ using over 8 hours, ${ }^{11}$ and 3 using 9 hours, ${ }^{16,17,21}$ after the first rFVIIa treatment. With regard to studies evaluating the hemostatic efficacy of rFVIIa in surgical procedures, the 2 studies presented here based the evaluation on the investigators' assessment at discontinuation of therapy or at postoperative day $10^{20}$ or the need for an escape dose of rFVIIa during the study. ${ }^{15}$ The considerable heterogeneity in the assessment of hemostatic efficacy and in sampling time points is in agreement with reports from nonrandomized studies. ${ }^{10,22-25,32-34,37-39}$ Obviously, this constitutes a significant problem for the interpretation and comparison of results from the studies of patients with hemophilia. Thus, data interpretation and the comparison of efficacy in the future studies on patients with hemophilia would be improved if efficacy parameters were standardized.

\section{rFVIla and adverse thromboembolic events}

Concern about the potential risk of thromboembolic events secondary to rFVIIa administration has been discussed. ${ }^{40,41}$ In 8 studies reviewed here, 2 reported adverse thromboembolic events. ${ }^{15,20}$ In the study by Shapiro et al, ${ }^{15} 1$ patient in the $35 \mu \mathrm{g} / \mathrm{kg} \mathrm{rFVIIa-treated} \mathrm{group} \mathrm{developed} \mathrm{thrombosis} \mathrm{of} \mathrm{the}$ right internal jugular vein on the second day following central venous catheter placement. Meanwhile, in the study by Pruthi et al, ${ }^{20} 1$ patient in the BI group developed thrombosis of the popliteal and proximal peroneal veins, documented by Doppler ultrasonography on day 10 after surgery. Additionally, 2 reviews reported adverse thromboembolic events following rFVIIa treatment in patients with hemophilia from 1996 to April $2003^{42}$ and from May 2003 to $2006 .{ }^{43}$ In total, 55 thromboembolic events are reported among approximately 1.5 million standard doses $(90 \mu \mathrm{g} / \mathrm{kg})$ administered to a $40-\mathrm{kg}$ individual. Given these data, the number of thromboembolic events in this patient population is approximately 3.67 per 100,000 infusions, which is quite low. Consequently, rFVIIa administration to inhibitor-expressing patients with hemophilia appears safe due to a lower incidence of thromboembolic events than that reported for other clotting factor concentrates. ${ }^{42,43}$

\section{Congenital platelet deficiencies}

No RCTs describing the safety and efficacy of rFVIIa treatment in patients with congenital platelet disorders exist. 
A number of reports suggest that rFVIIa administration to patients with Glanzmann's thrombasthenia and Bernard Souliers syndrome may be beneficial, while others do not support its clinical use. ${ }^{44}$ As rFVIIa is only administered to patients with congenital platelet disorders when other treatment options fail, this may justify its use despite the lack of scientific evidence.

It is worrisome that rFVIIa treatment in clotting factor inhibitor - expressing patients with hemophilia is based on weight alone. Furthermore, because there is a consensus among the scientific community that the coagulopathy in hemophilia is related to impaired thrombin generation, it is surprising to find that assays only reflecting $2 \%-3 \%$ of the patient's ability to generate thrombin, such as activated partial thromboplastin time (aPTT) and prothrombin time, are used. These plasma-based coagulation tests were developed more than 50 years ago, when it was believed that the hemostatic process could be explained by the clotting cascade. ${ }^{45,46}$ Furthermore, they are developed to monitor anticoagulation and have consistently been shown to correlate poorly with clinical bleeding conditions. ${ }^{47-56}$

A cell-based model of hemostasis was introduced in 1994, emphasizing the importance of both platelets and tissue factor (TF), an initiator of coagulation, for proper hemostasis. ${ }^{57,58}$ The coagulation process involves the following 3 phases: initiation, amplification, and propagation. During initiation, circulating FVIIa forms a complex with exposed TF on a TF-bearing cell. This complex converts FIX and FX into their active forms, FIXa and FXa, respectively. During the amplification, the FXa-activated factor $\mathrm{V}(\mathrm{FVa})$ - TF complex acts on prothrombin to generate a small amount of thrombin that is responsible for initiating several events, including platelet activation. Finally, propagation takes place on the surface of the activated platelet, where FVa and FVIIIa are bound. FIX and FX are converted to FIXa and FXa, respectively, forming the tenase and prothrombinase complexes, respectively, which rapidly generate a large "thrombin burst." The kinetics of this burst influence clot strength and stability by activating FXIII to FXIIIa and TAFI to TAFIa in a concentrationdependent manner. ${ }^{59}$ Consequently, assays reflecting the patient's ability to generate thrombin are preferable for monitoring hemostasis.

Whole-blood viscoelastic assays, such as thromboelastography (TEG ${ }^{\circledR}$; Haemoscope Corp., Niles, Illinois, USA) and rotational thromboelastometry (ROTEM ${ }^{\circledR}$; Munich, Germany), have consistently been shown to be superior to conventional plasma-based coagulation assays for predicting the need for blood transfusion in patients with severe bleeding, as well as, for directing the treatment with plasma and platelets in nonhemophilic patients. ${ }^{51-54,60-71}$ The scientific rationale for this superiority was delineated by Rivard et al, ${ }^{72}$ who demonstrated a correlation between total thrombus generation over a period of time, as evaluated by TEG, and the concentration of generated thrombin-antithrombin complexes. Coagulation-factor deficiency and/or thrombocytopenia/pathy likely results in impaired thrombin generation, thus reducing the clot formation and stability, which is indicated by an abnormal TEG tracing. ${ }^{51-54,60-70,73,74}$ Given this, it seems rationale to monitor hemostasis in inhibitor-expressing patients with hemophilia by TEG/ROTEM, as suggested by Yoshioka et $\mathrm{al}^{73}$ over 10 years ago and by Sorensen and Ingerslev ${ }^{74}$ more recently. This is supported by Bassus et $a{ }^{75}$ who found that the administration of FVIII concentrate in patients with hemophilia A correlated linearly with increased FVIII activity, as evaluated by aPTT. On the contrary, thrombin generation and maximal clot strength, evaluated by the thrombin generation test (TGT) and TEG, showed no such correlation. Instead, substituting whole-blood samples ex vivo with $1 \mathrm{U} / \mathrm{mL}$ FVIII resulted in maximal hemostatic effect of FVIII, as evaluated by both TGT and TEG maximal clot strength. It also became evident that $30 \%$ FVIII activity was sufficient to achieve more than $90 \%$ of maximal thrombin generation and clot strength. Additionally, FVIII substitution up to a plasma activity level greater than $90 \%$ did not further enhance the hemostatic effect. With regard to inhibitor-expressing patients, Trowbridge et $\mathrm{al}^{76}$ also reported the successful use of TEG to guide the administration of rFVIIa to patients with hemophilia, who were difficult to manage based on conventional plasma-based coagulation assays.

The systematic use of viscoelastic whole-blood assays has the potential to significantly improve the treatment of inhibitor-expressing patients with hemophilia. Instead of administering rFVIIa at doses related to patient weight, an individual dosing regimen based on the amount of FVIIa needed to establish maximal thrombin generation and clot strength seems preferable.

\section{Disclosure}

The authors report no conflicts of interest in this work.

\section{References}

1. Oldenburg J, Dolan G, Lemm G. Haemophilia care then, now and in the future. Haemophilia. 2009;15(Suppl 1):S2-S7.

2. Dimichele D. Inhibitors: resolving diagnostic and therapeutic dilemmas. Haemophilia. 2002;8:280-287. 
3. Yee TT, Pasi KJ, Lilley PA, Lee CA. Factor VIII inhibitors in haemophiliacs: a single-centre experience over 34 years, 1964-97. $\mathrm{Br}$ J Haematol. 1999;104:909-914.

4. Kreuz W, Ettingshausen CE, Zyschka A, et al. Inhibitor development in previously untreated patients with hemophilia A: a prospective long-term follow-up comparing plasma-derived and recombinant products. Semin Thromb Hemost. 2002;28:285-290.

5. Goodeve A. The incidence of inhibitor development according to specific mutations - and treatment? Blood Coagul Fibrinolysis. 2003;14 (Suppl 1):S17-S21.

6. Morfini M, Haya S, Tagariello G, et al. European study on orthopaedic status of haemophilia patients with inhibitors. Haemophilia. 2007;13:606-612.

7. Sjamsoedin LJ, Heijnen L, Mauser-Bunschoten EP, et al. The effect of activated prothrombin-complex concentrate (FEIBA) on joint and muscle bleeding in patients with hemophilia $\mathrm{A}$ and antibodies to factor VIII. A double-blind clinical trial. $N$ Engl J Med. 1981;305: 717-721.

8. Hedner U. Mechanism of action, development and clinical experience of recombinant FVIIa. J Biotechnol. 2006;124:747-757.

9. Pan-Petesch B, Laguna P, Mital A, et al. Single-dose (270 microg kg(-1)) recombinant activated factor VII for the treatment and prevention of bleeds in haemophilia A patients with inhibitors: experience from seven European haemophilia centres. Haemophilia. 2009;15:760-765.

10. Key NS, Aledort LM, Beardsley D, et al. Home treatment of mild to moderate bleeding episodes using recombinant factor VIIa (Novoseven) in haemophiliacs with inhibitors. Thromb Haemost. 1998; 80:912-918.

11. Lusher JM, Roberts HR, Davignon G, et al. A randomized, doubleblind comparison of two dosage levels of recombinant factor VIIa in the treatment of joint, muscle and mucocutaneous haemorrhages in persons with haemophilia A and B, with and without inhibitors. rFVIIa study group. Haemophilia. 1998;4:790-798.

12. Laurian Y, Goudemand C, Négrier C, et al. Use of recombinant activated factor VII as first-line therapy for bleeding episodes in haemophiliacs with factor VIII or IX inhibitors (NOSEPAC study). Blood Coagul Fibrinolysis. 1998;9:S155-S156.

13. Monroe DM, Hoffman M, Oliver JA, Roberts HR. Platelet activity of high-dose factor VIIa is independent of tissue factor. Br J Haematol. 1997;99:542-547.

14. Lisman T, Mosnier LO, Lambert T, et al. Inhibition of fibrinolysis by recombinant factorVIIa in plasma from patients with severe hemophiliaA. Blood. 2002;99:175-179.

15. Shapiro AD, Gilchrist GS, Hoots WK, et al. Prospective, randomised trial of two doses of rFVIIa (NovoSeven) in haemophilia patients with inhibitors undergoing surgery. Thromb Haemost. 1998;80:773-778.

16. Santagostino E, Mancuso ME, Rocino A, et al. A prospective randomized trial of high and standard dosages of recombinant factor VIIa for treatment of hemarthroses in hemophiliacs with inhibitors. $J$ Thromb Haemost. 2006;4:367-371.

17. Kavakli K, Makris M, Zulfikar B, et al. Home treatment of haemarthroses using a single dose regimen of recombinant activated factor VII in patients with haemophilia and inhibitors. A multi-centre, randomised, double-blind, cross-over trial. Thromb Haemost. 2006;95:600-605.

18. Astermark J, Donfield SM, DiMichele DM, et al. A randomized comparison of bypassing agents in hemophilia complicated by an inhibitor: the FEIBA NovoSeven Comparative (FENOC) Study. Blood. 2007;109:546-551.

19. Konkle BA, Ebbesen LS, Erhardtsen E, et al. Randomized, prospective clinical trial of recombinant factor VIIa for secondary prophylaxis in hemophilia patients with inhibitors. J Thromb Haemost. 2007;5:1904-1913.

20. Pruthi RK, Mathew P, Valentino LA, et al. Haemostatic efficacy and safety of bolus and continuous infusion of recombinant factor VIIa are comparable in haemophilia patients with inhibitors undergoing major surgery. Results from an open-label, randomized, multicenter trial. Thromb Haemost. 2007;98:726-732.
21. Young G, Shafer FE, Rojas P, Seremetis S. Single 270 microg kg(-1)dose rFVIIa vs standard 90 microg $\mathrm{kg}(-1)$-dose rFVIIa and APCC for home treatment of joint bleeds in haemophilia patients with inhibitors: a randomized comparison. Haemophilia. 2008;14:287-294.

22. Obergfell A, Auvinen MK, Mathew P. Recombinant activated factor VII for haemophilia patients with inhibitors undergoing orthopaedic surgery: a review of the literature. Haemophilia. 2008;14: 233-241.

23. Solimeno LP, Perfetto OS, Pasta G, Santagostino E. Total joint replacement in patients with inhibitors. Haemophilia. 2006;12 (Suppl 3):113-116.

24. Rodriguez-Merchan EC, Wiedel JD, Wallny T, et al. Elective orthopaedic surgery for inhibitor patients. Haemophilia. 2003;9:625-631.

25. Santagostino E, Gringeri A, Mannucci PM. Home treatment with recombinant activated factor VII in patients with factor VIII inhibitors: the advantages of early intervention. Br J Haematol. 1999;104: 22-26.

26. Goldstein B, Geldziler B, Bjerre J, Seremetis S. Evidence-based use of recombinant FVIIa (NovoSeven, NiaStase) for the treatment of hemophilia with inhibitors in children and adolescents. Transfus Apher Sci. 2008;38:25-32.

27. Hotchkiss RS, Tinsley KW, Swanson PE, Karl IE. Endothelial cell apoptosis in sepsis. Crit Care Med. 2002;30:S225-S228.

28. Doshi SN, Marmur JD. Evolving role of tissue factor and its pathway inhibitor. Crit Care Med. 2002;30:S241-S250.

29. Ludlam CA, Smith MP, Morfini M, et al. A prospective study of recombinant activated factor VII administered by continuous infusion to inhibitor patients undergoing elective major orthopaedic surgery: a pharmacokinetic and efficacy evaluation. Br J Haematol. 2003;120:808-813.

30. Santagostino E, Morfini M, Rocino A, et al. Relationship between factor VII activity and clinical efficacy of recombinant factor VIIa given by continuous infusion to patients with factor VIII inhibitors. Thromb Haemost. 2001;86:954-958.

31. Smith MP, Ludlam CA, Collins PW, et al. Elective surgery on factor VIII inhibitor patients using continuous infusion of recombinant activated factor VII: plasma factor VII activity of $10 \mathrm{IU} / \mathrm{mL}$ is associated with an increased incidence of bleeding. Thromb Haemost. 2001;86:949-953.

32. Negrier C, Goudemand J, Sultan Y, et al. Multicenter retrospective study on the utilization of FEIBA in France in patients with factor VIII and factor IX inhibitors. French FEIBA Study Group. Factor eight bypassing activity. Thromb Haemost. 1997;77:1113-1119.

33. Dimichele D, Negrier C. A retrospective postlicensure survey of FEIBA efficacy and safety. Haemophilia. 2006;12:352-362.

34. Smejkal P, Brabec P, Matyskova M, et al. FEIBA in treatment of acute bleeding episodes in patients with haemophilia A and factor VIII inhibitors: a retrospective survey in regional haemophilia centre. Haemophilia. 2009;15:743-751.

35. Aledort LM, Haschmeyer RH, Pettersson H. A longitudinal study of orthopaedic outcomes for severe factor-VIII-deficient haemophiliacs. The Orthopaedic Outcome Study Group. J Intern Med. 1994;236:391-399.

36. Szucs TD, Offner A, Kroner B, et al. Resource utilisation in haemophiliacs treated in Europe: results from the European study on socioeconomic aspects of haemophilia care. The European Socioeconomic Study Group. Haemophilia. 1998;4:498-501.

37. Cooper HA, Jones CP, Campion E, et al. Rationale for the use of high dose rFVIIa in a high-titre inhibitor patient with haemophilia B during major orthopaedic procedures. Haemophilia. 2001;7:517-522.

38. Young G, McDaniel M, Nugent DJ. Prophylactic recombinant factor VIIa in haemophilia patients with inhibitors. Haemophilia. 2005;11:203-207.

39. Morfini M, Auerswald G, Kobelt RA, et al. Prophylactic treatment of haemophilia patients with inhibitors: clinical experience with recombinant factor VIIa in European haemophilia centres. Haemophilia. 2007;13:502-507. 
40. Aledort LM. Comparative thrombotic event incidence after infusion of recombinant factor VIIa versus factor VIII inhibitor bypass activity. J Thromb Haemost. 2004;2:1700-1708.

41. O'Connell NM, Riddell AF, Pascoe G, et al. Recombinant factor VIIa to prevent surgical bleeding in factor XI deficiency. Haemophilia. 2008; $14: 775-781$.

42. Abshire T, Kenet G. Recombinant factor VIIa: review of efficacy, dosing regimens and safety in patients with congenital and acquired factor VIII or IX inhibitors. J Thromb Haemost. 2004;2:899-909.

43. Abshire T, Kenet G. Safety update on the use of recombinant factor VIIa and the treatment of congenital and acquired deficiency of factor VIII or IX with inhibitors. Haemophilia. 2008;14:898-902.

44. Franchini M. The use of recombinant activated factor VII in platelet disorders: a critical review of the literature. Blood Transfus. 2009;7:24-28.

45. Davie EW, Ratnoff OD. Waterfall sequence for intrinsic blood clotting. Science. 1964;145:1310-1312.

46. MacFarlane RG. An enzyme cascade in the blood clotting mechanism, and its function as a biochemical amplifier. Nature. 1964; 202:498-499.

47. Aoki N, Wall MJ, Demsar J, et al. Predictive model for survival at the conclusion of a damage control laparotomy. Am J Surg. 2000; 180:540-544.

48. Brohi K, Singh J, Heron M, Coats T. Acute traumatic coagulopathy. J Trauma. 2003;54:1127-1130.

49. MacLeod JB, Lynn M, McKenney MG, et al. Early coagulopathy predicts mortality in trauma. J Trauma. 2003;55:39-44.

50. Martini WZ, Cortez DS, Dubick MA, et al. Thrombelastography is better than PT, aPTT, and activated clotting time in detecting clinically relevant clotting abnormalities after hypothermia, hemorrhagic shock and resuscitation in pigs. J Trauma. 2008;65:535-543.

51. Plotkin AJ, Wade CE, Jenkins DH, et al. A reduction in clot formation rate and strength assessed by thrombelastography is indicative of transfusion requirements in patients with penetrating injuries. J Trauma. 2008;64(Suppl 2):S64-S68.

52. Gravlee GP, Arora S, Lavender SW, et al. Predictive value of blood clotting tests in cardiac surgical patients. Ann Thorac Surg. 1994; 58:216-221.

53. Segal JB, Dzik WH. Paucity of studies to support that abnormal coagulation test results predict bleeding in the setting of invasive procedures: an evidence-based review. Transfusion. 2005;45:1413-1425.

54. Murray D, Pennell B, Olson J. Variability of prothrombin time and activated partial thromboplastin time in the diagnosis of increased surgical bleeding. Transfusion. 1999;39:56-62.

55. Shapiro S, Sherwin B, Gordimer H. Postoperative thromboembolization: the platelet count and the prothrombin time after surgical operations: a simple method for detecting reductions and elevations of the prothrombin concentration (or activity) of the blood plasma. Ann Surg. 1942;116:175-183.

56. Proctor RR, Rapaport SI. The partial thromboplastin time with kaolin. A simple screening test for first stage plasma clotting factor deficiencies. Am J Clin Pathol. 1961;36:212-219.

57. Monroe DM, Roberts HR, Hoffman M. Platelet procoagulant complex assembly in a tissue factor-initiated system. Br J Haematol. 1994;88:364-371.

58. Monroe DM, Hoffman M. What does it take to make the perfect clot? Arterioscler Thromb Vasc Biol. 2006;26:41-48.

Drug Design, Development and Therapy

\section{Publish your work in this journal}

Drug Design, Development and Therapy is an international, peerreviewed open-access journal that spans the spectrum of drug design and development through to clinical applications. Clinical outcomes, patient safety, and programs for the development and effective, safe, and sustained use of medicines are a feature of the journal, which
59. Wolberg AS. Thrombin generation and fibrin clot structure. Blood Rev. 2007;21:131-142.

60. Kang YG, Martin DJ, Marquez J, et al. Intraoperative changes in blood coagulation and thrombelastographic monitoring in liver transplantation. Anesth Analg. 1985;64:888-896.

61. McNicol PL, Liu G, Harley ID, et al. Patterns of coagulopathy during liver transplantation: experience with the first 75 cases using thrombelastography. Anaesth Intensive Care. 1994;22:659-665.

62. Spiess BD, Gillies BS, Chandler W, Verrier E. Changes in transfusion therapy and reexploration rate after institution of a blood management program in cardiac surgical patients. $J$ Cardiothorac Vasc Anesth. 1995;9:168-173.

63. Shore-Lesserson L, Manspeizer HE, DePerio M, et al. Thromboelastography-guided transfusion algorithm reduces transfusions in complex cardiac surgery. Anesth Analg. 1999;88:312-319.

64. Manikappa S, Mehta Y, Juneja R, Trehan N. Changes in transfusion therapy guided by thromboelastograph in cardiac surgery. Ann Card Anaesth. 2001;4:21-27.

65. Anderson L, Quasim I, Soutar R, et al. An audit of red cell and blood product use after the institution of thromboelastometry in a cardiac intensive care unit. Transfus Med. 2006;16:31-39.

66. Welsby IJ, Jiao K, Ortel TL, et al. The kaolin-activated thrombelastograph predicts bleeding after cardiac surgery. $J$ Cardiothorac Vasc Anesth. 2006;20:531-535.

67. Kaufmann CR, Dwyer KM, Crews JD, et al. Usefulness of thrombelastography in assessment of trauma patient coagulation. J Trauma. 1997;42:716-720.

68. Johansson PI. Treatment of massively bleeding patients: introducing real-time monitoring, transfusion packages and thrombelastography (TEGR). ISBT Sci Ser. 2007;2:159-167.

69. Johansson PI, Bochsen L, Stensballe J, Secher NH. Transfusion packages for massively bleeding patients: the effect on clot formation and stability as evaluated by Thrombelastograph (TEG(R)). Transfus Apher Sci. 2008;39:3-8.

70. Johansson PI, Stensballe J. Effect of haemostatic control resuscitation on mortality in massively bleeding patients: a before and after study. Vox Sang. 2009;96:111-118.

71. Johansson PI, Stissing T, Bochsen L, Ostrowski SR. Thrombelastography and tromboelastometry in assessing coagulopathy in trauma. Scand J Trauma Resusc Emerg Med. 2009;17:45.

72. Rivard GE, Brummel-Ziedins KE, Mann KG, et al. Evaluation of the profile of thrombin generation during the process of whole blood clotting as assessed by thrombelastography. $J$ Thromb Haemost. 2005;3:2039-2043.

73. Yoshioka A, Nishio K, Shima M. Thrombelastgram as a hemostatic monitor during recombinant factor VIIa treatment in hemophilia A patients with inhibitor to factor VIII. Haemostasis. 1996;26:139-142.

74. Sorensen B, Ingerslev J. Tailoring haemostatic treatment to patient requirements - an update on monitoring haemostatic response using thrombelastography. Haemophilia. 2005;11(Supp1 1):1-6.

75. Bassus S, Wegert W, Krause M, et al. Platelet-dependent coagulation assays for factor VIII efficacy measurement after substitution therapy in patients with haemophilia A. Platelets. 2006;17:378-384.

76. Trowbridge CC, Stammers AH, Ciccarelli N, Klayman M. Dose titration of recombinant factor VIIa using thromboelastograph monitoring in a child with hemophilia and high titer inhibitors to factor VIII: a case report and brief review. J Extra Corpor Technol. 2006;38:254-259.

\section{Dovepress}

has also been accepted for indexing on PubMed Central. The manuscript management system is completely online and includes a very quick and fair peer-review system, which is all easy to use. Visit http://www.dovepress.com/testimonials.php to read real quotes from published authors.

Submit your manuscript here: http://www.dovepress.com/drug-design-development-and-therapy-journal 